\title{
Enhancement of Newton Law of Cooling Method based on Asante's Algorithm with Henssge Nomogram Method in Estimating the Time of Death
}

\author{
Noor Maizura Mohamad Noor, Muhammad Bin Che Abdullah, and Zuriana Abu Bakar
}

\begin{abstract}
Time of death is referred as the time of elapse since a person died. It acts as a significant factor in crime investigation which functions to address the fact and later identify the truth. The data collected from the time of death must be interpreted profoundly and the report produced afterwards must be easily understood by non-scientist. A variety of methods had been used in estimating the time of death and it is different according to the variables used. However, the result produces still imprecise and undependable. Enhancement is an improvement in making something become more agreeable. Asante's algorithm through Newton Law of Cooling method has brought a great impact in estimating the time of death in crime investigation, Although the algorithm needs further improvisation, it had positively assist in proving that the shorter the post mortem interval, more accurate and reliable the time of death estimation. Therefore, enhancement of Newton Law of Cooling method with Henssge nomogram method through its corrective factor could assist in making the result to become more precise and dependable as Henssge nomogram method itself devote a big influence in estimating the time of death.
\end{abstract}

Index Terms-Algorithm, method, time of death.

\section{INTRODUCTION}

Technology is a branch of knowledge dealing with engineering or applied sciences. It acts as a medium to help people with communication, doing works, publish an interesting advertisement or even promote product worldwide. Technology can be applied in many fields either to the education field, finance field, engineering field or any other field which concern. Technology had been attached to peoples as a proof that human civilization had become better than before. It also shows that human evolve along with the changes of time.

Behind a great technology comes a great development. Development is the systematic use of scientific and technical knowledge to meet specific objectives or requirements. As the aim is to meet specific objectives or requirements, development provides the technology with a direction or a limit on how far it can evolve but still meeting the requirement. To ensure a progressive development, a clear and reliable method is needed. Method is a core or main component in development. It is the main things which control the development of a system to be on the right track

Manuscript received December 9, 2015; revised March 2, 2016. This paper had been sponsored by Grant from Ministry of Higher Education (MOHE) in Fundamental Research Grant Scheme with vot number 59289.

The authors are with Universiti Malaysia Terengganu (UMT), Malaysia (e-mail: maizura@umt.edu.my, muhammadcheabdullah@gmail.com, zuriana@umt.edu.my) or meet the requirement. In regards with forensic science fields, method plays an important role in investigation. An investigation is an examination, a study, a survey and a research of facts or circumstances, situations, incidents and scenarios, either related or not, for the purpose of rendering a conclusion of the proof [1]. When one investigates, he or she makes a systematic inquiry, closely analyzes and inspects while dissect and scrutinize information. An investigation, therefore, is based upon a complete and whole evaluation and not conjecture, speculation or supposition.

The method leads the investigation to its solution. Without a proper method, an investigation could end in failure or even cannot be accomplished. A method called Newton Law of Cooling has been used in forensic science in estimating the time of death [2]. This method takes temperature as its main factor in determining the time of death. Time of death is the time elapsed since a person died [3]. Usually estimating the time of death is used in criminal investigation. Criminal investigations are conducted primarily for the prevention of crimes. When crimes occur, Law Enforcement is responsible to the community it serves and must discharge it's duty by immediately investigating such incidents. Ideally the investigation will cause the violator to appear before a court so as to answer for his or her behavior. Ultimately and probably most important, is that the investigation, detection and apprehension of the criminal, effectually serves to curtail recidivism thereby reducing overall crime.

Related to method for estimating the time of death, an algorithm had been proposed by Asante for time of death estimation. Asante's algorithm is a step by step process which had been developed for estimating the time of death [2]. The Asante's algorithm was based on Newton Law of Cooling method. It is an application which can estimate the time of death. Another method which plays the same role is Henssge nomogram method. Henssge nomogram method is a method which using nomogram scale as its main function in estimating the time of death. The approach which had been used to estimate the time of death is through drawing on the scale and the time of death will be shown as a result. [4] in his paper had test method which is related to estimate the time of death and found Henssge nomogram is the best and accurate method in estimating the time of death. Therefore, this study focus on combining between these two methods to assist in making the time of death estimation becomes more accurate and reliable.

The remainder of this paper is organized as follows. Section II discusses on related works in estimating the time of death, Section III explained the algorithm that had been 
proposed. The process in estimating the time of death for this study is describe in Section IV, the results from the improvement of algorithm is shown in Section $\mathrm{V}$ and finally concluded with the conclusion and discussion in Section VI.

\section{RELATED WORKS IN ESTIMATING TIME OF DEATH}

The approach symbolizes as an idea which intends to deal with a problem or a situation. As for the approach of algorithm in estimating the time of death, it is symbolize as an action which intend to deal with time of death estimation. Table I describes the approach which had been used to solve crime cases through the field covered and the approach which concern on estimating the time of death.

TABLE I: THE ALGORITHM APPROACH IN DECISION MAKING AND CRIME INVESTIGATION

\begin{tabular}{|c|c|c|}
\hline $\begin{array}{l}\text { Types of } \\
\text { Algorithm } \\
\text { Used }\end{array}$ & Field Covered & Remarks \\
\hline $\begin{array}{l}\text { Shortest } \\
\text { path } \\
\text { algorithm }\end{array}$ & $\begin{array}{l}\text { Criminal } \\
\text { Networks }\end{array}$ & $\begin{array}{l}\text { Efficient for small, kidnapped } \\
\text { network and large, sparse narcotic } \\
\text { network [5]. }\end{array}$ \\
\hline $\begin{array}{l}\text { Rule-Based } \\
\text { Algorithm }\end{array}$ & $\begin{array}{l}\text { Crime Data } \\
\text { Mining }\end{array}$ & $\begin{array}{l}\text { An appropriate methodology to } \\
\text { uncover previous unknown structural } \\
\text { pattern [6]. }\end{array}$ \\
\hline $\begin{array}{l}\text { Bayesian } \\
\text { Network } \\
\text { algorithm }\end{array}$ & $\begin{array}{l}\text { Crime } \\
\text { Investigation }\end{array}$ & $\begin{array}{l}\text { Provide evidence collection strategies } \\
\text { that are effective at answering } \\
\text { multiple queries [7]. }\end{array}$ \\
\hline $\begin{array}{l}\text { Rule } \\
\text { extraction } \\
\text { algorithm }\end{array}$ & $\begin{array}{l}\text { Crime } \\
\text { Prevention }\end{array}$ & $\begin{array}{l}\text { Support police manager is assessing } \\
\text { more appropriate law enforcement } \\
\text { strategies and improve the use of } \\
\text { police duty deployment for crime } \\
\text { prevention [8]. }\end{array}$ \\
\hline $\begin{array}{l}\text { MV and } \\
\text { Apriori } \\
\text { algorithm }\end{array}$ & $\begin{array}{l}\text { Future Crime in } \\
\text { Crime Data } \\
\text { Mining }\end{array}$ & $\begin{array}{l}\text { For knowledge discovery from crime } \\
\text { record and help increase the predictive } \\
\text { accuracy [9]. }\end{array}$ \\
\hline $\begin{array}{l}\text { Rule-Based } \\
\text { Algorithm }\end{array}$ & $\begin{array}{l}\text { Estimating the } \\
\text { time of death }\end{array}$ & $\begin{array}{l}\text { More accurate time of death } \\
\text { estimation in shorter postmortem } \\
\text { period [10]. }\end{array}$ \\
\hline
\end{tabular}

Note: Comparison from various paper regarding algorithm approach.

Table I indicates that an algorithm had been used in a variety of areas such as in criminal networks, crime data mining, crime investigation, crime prevention, future crime in crime data mining and estimating the time of death. It represented as a process which helps in unriddling many crimes cases. Thus, it resolves that one of the ways for finding the better solution is through algorithm. This study is focuses on constructing an algorithm for the time of death determination. It seems that conceptualization of algorithm by [10] is the only methodology that focuses on time of death estimation. Thus, this study will apply an algorithm introduced by [10]. However, the algorithm still could not provide a good result since many factors were not considered in the time of death calculation. In addition, there was a prototype of the system which only performed the calculating of algorithm without producing the report or anything related documents that could be a proof in helping the crime investigation. Furthermore, [10] highlighted that the automation of the algorithm could truly assist crime investigator in estimating the time of death.

According to [11] the longer the postmortem interval, the less precise the estimate of the interval. Thus, it can be concludes that the shorter the postmortem interval or the time elapse to estimate the time of death, the time estimation will become more accurate.

\section{A. Asante's Algorithm in Time of Death Estimation}

The automation of the algorithm could truly assist crime investigator in estimating time of death [10]. From the analysis, the algorithm were observe to show that the shorter the postmortem interval, the more accurate the time of death estimation [10]. However, since many factors were not considered in the time of death calculation the algorithm could not provide a good result and reach its inaccuracy at low temperature difference between the rectal and ambient temperature. Accordingly, the present study attempts to develop a fully computerized algorithm of the time death estimation. Reliability played the most important principle which can only be provided empirically by statistical analyses of field studies. By increasing the reliability of Asante's algorithm, it could truly help increase the effectiveness in crime investigation. Thus, the crime investigator will not waste time in searching for clues or an evidences and could slightly made an early conclusion from the crime cases.

\section{B. Pekka's Observation in Time of Death Estimation}

Pekka has published five methods that have been used in estimating the time of death which is Henssge nomogram method, James and Knight method, triple-exponential method, Marshall method and rule of thumb methods [4]. These methods were recent methods that had been used in solving the time of death in crime investigation. Based on five methods tested by [4] for estimating the time of death, it had been found that Henssge nomogram method with its correction factor was the most versatile and gave the most precise results in homicide and accidental drowning cases [4]. Since the case had been tested on both land and water, it is suitable for Henssge nomogram method to be combined with the Asante's algorithm as its approach similar to Henssge nomogram method in term of variables used. Thus, an enhance algorithm could be developed. The architecture of the enhance algorithm is as follows:

From Fig. 1, it can be seen that the enhance algorithm is based on criteria provided from the crime scene which are time of cadaver or corpse found, rectum temperature, room temperature, mass of cadaver or corpses, condition of corpse or cadaver body, condition of clothes of the corpse or cadaver, layer of the clothes, condition of air and condition of water. Next, all of the criteria provided will insert into a Graphical User Interface (GUI) System based on the time of death algorithm that been developed. Then, the data that had been input into the algorithm will be analyzed to predict the time of death. Finally, the estimation of time of death will be stored in the database and the reports are produced.

\section{Algorithm to Estimate Time OF DeAth}

An algorithm is a step by step process for solving a problem. The algorithm for estimating the time of death presents the step by step process for estimating the time of death. The algorithm is as shown in Figure II below:

Input: rectum temperature, room temperature, mass of cadaver, condition of body, condition of cloth, layer of cloth, condition of air, and condition of water

Output: time of death

Before estimate the time of death, all the input needed 
must be inserted into the algorithm. The input intends to be the variable needed in calculating the time of death. The algorithm will calculate the time of death based on the data attain from the input.

Procedure of improved algorithm:

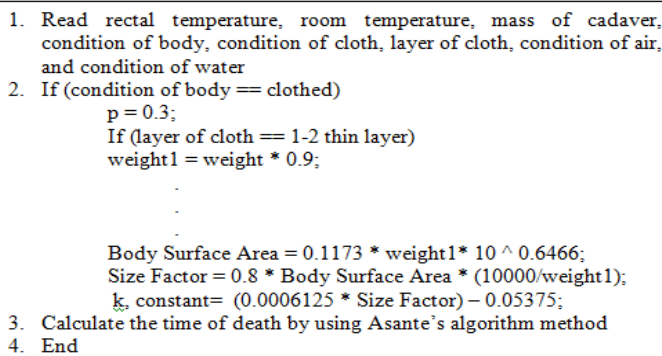

1. Read rectal temperature, room temperature, mass of cadaver, condition of body, condition of cloth, layer of cloth, condition of air, and condition of water

2. If (condition of body $==$ clothed)$$
\text { If (layer of cloth }==1-2 \text { thin layer) }
$$$$
\text { weight } 1=\text { weight } * 0.9
$$

Body Surface Area $=0.1173$ * weight $1 * 10^{\wedge} 0.6466$;

Size Factor $=0.8$ * Body Surface Area * (10000/weight 1$)$;

$\mathrm{k}$, constant $=(0.0006125 *$ Size Factor $)-0.05375$;

3. Calculate the time of death by using Asante's algorithm method

End

Fig. 2. Time of death algorithm.

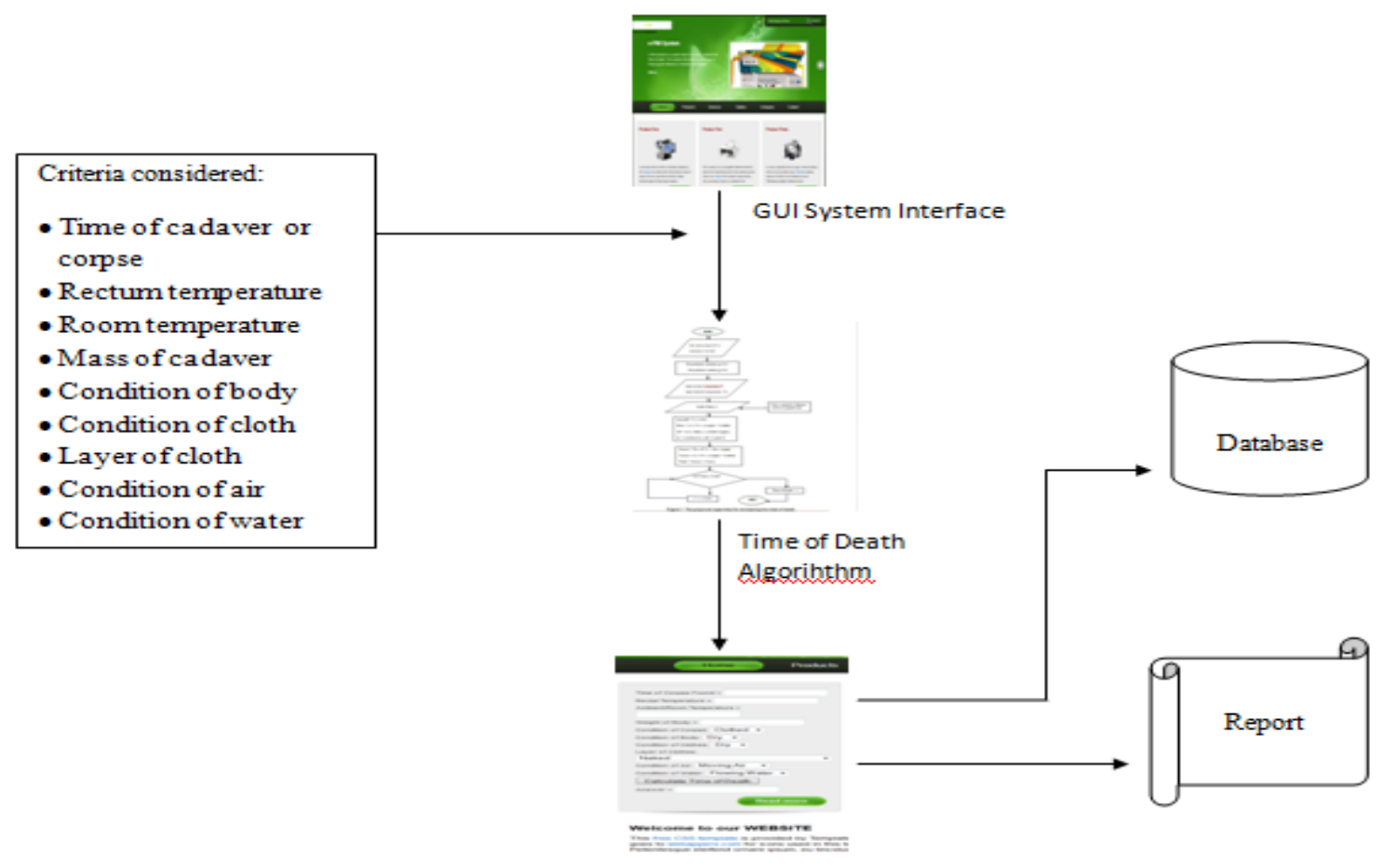

Analysis Process of Time of Death

Fig. 1. Architecture for time of death algorithm.

TABLE II: CORRECTIVE FACTOR OF HENSSGE NOMOGRAM METHOD

\begin{tabular}{|c|c|c|c|c|c|}
\hline $\begin{array}{l}\text { Dry } \\
\text { clothing / } \\
\text { Covering }\end{array}$ & In air & $\begin{array}{l}\text { Corrective } \\
\text { Factors }\end{array}$ & $\begin{array}{l}\text { Wet through } \\
\text { clothing/ covering } \\
\text { wet body surface }\end{array}$ & In air & In water \\
\hline $\mathrm{n} / \mathrm{a}$ & $\mathrm{n} / \mathrm{a}$ & 0.35 & naked & $\mathrm{n} / \mathrm{a}$ & flowing \\
\hline $\mathrm{n} / \mathrm{a}$ & $\mathrm{n} / \mathrm{a}$ & 0.50 & naked & $\mathrm{n} / \mathrm{a}$ & still \\
\hline $\mathrm{n} / \mathrm{a}$ & $\mathrm{n} / \mathrm{a}$ & 0.70 & $\mathrm{n} / \mathrm{a}$ & moving & $\mathrm{n} / \mathrm{a}$ \\
\hline $\mathrm{n} / \mathrm{a}$ & $\mathrm{n} / \mathrm{a}$ & 0.70 & $\mathrm{n} / \mathrm{a}$ & moving & $\mathrm{n} / \mathrm{a}$ \\
\hline naked & moving & 0.75 & $\mathrm{n} / \mathrm{a}$ & moving & $\mathrm{n} / \mathrm{a}$ \\
\hline $\begin{array}{l}1-2 \text { thin } \\
\text { layer }\end{array}$ & moving & 0.90 & $\mathrm{n} / \mathrm{a}$ & still & $\mathrm{n} / \mathrm{a}$ \\
\hline naked & still & 1.00 & $\mathrm{n} / \mathrm{a}$ & still & $\mathrm{n} / \mathrm{a}$ \\
\hline $\begin{array}{l}1-2 \text { thin } \\
\text { layer }\end{array}$ & still & 1.10 & $\mathrm{n} / \mathrm{a}$ & $\mathrm{n} / \mathrm{a}$ & $\mathrm{n} / \mathrm{a}$ \\
\hline $\begin{array}{l}2-3 \text { thin } \\
\text { layer }\end{array}$ & $\begin{array}{l}\text { moving } \\
\text { or still }\end{array}$ & 1.20 & $\mathrm{n} / \mathrm{a}$ & $\mathrm{n} / \mathrm{a}$ & $\mathrm{n} / \mathrm{a}$ \\
\hline $\begin{array}{l}1-2 \text { thick } \\
\text { layer }\end{array}$ & $\begin{array}{l}\text { moving } \\
\text { or still }\end{array}$ & 1.20 & $\mathrm{n} / \mathrm{a}$ & $\mathrm{n} / \mathrm{a}$ & $\mathrm{n} / \mathrm{a}$ \\
\hline $\begin{array}{l}3-4 \text { thin } \\
\text { layer }\end{array}$ & $\begin{array}{l}\text { moving } \\
\text { or still }\end{array}$ & 1.30 & $\mathrm{n} / \mathrm{a}$ & $\mathrm{n} / \mathrm{a}$ & $\mathrm{n} / \mathrm{a}$ \\
\hline $\begin{array}{l}\text { more } \\
\text { thin/thick } \\
\text { layer }\end{array}$ & $\begin{array}{l}\text { moving } \\
\text { or still }\end{array}$ & 1.40 & $\mathrm{n} / \mathrm{a}$ & $\mathrm{n} / \mathrm{a}$ & $\mathrm{n} / \mathrm{a}$ \\
\hline $\begin{array}{l}\text { thick } \\
\text { bedspread }\end{array}$ & $\begin{array}{l}\text { moving } \\
\text { or still }\end{array}$ & 1.80 & $\mathrm{n} / \mathrm{a}$ & $\mathrm{n} / \mathrm{a}$ & $\mathrm{n} / \mathrm{a}$ \\
\hline $\begin{array}{l}\text { thick } \\
\text { bedspread } \\
\text { \&clothing } \\
\text { combine }\end{array}$ & $\begin{array}{l}\text { moving } \\
\text { or still }\end{array}$ & 2.40 & $\mathrm{n} / \mathrm{a}$ & $\mathrm{n} / \mathrm{a}$ & $\mathrm{n} / \mathrm{a}$ \\
\hline
\end{tabular}




\section{Process in Estimating the Time OF DEATH}

Estimating the time of death become inaccurate at low temperature difference between the rectal and ambient temperatures [10], this study focuses to improve the Asante's algorithm to become more reliable in estimating the time of death. Asante's algorithm will be combining with Henssge nomogram corrective factors [12] to increase its sensitivity towards estimating the time of death. The corrective factors can be seen as in Table II:

\section{RESUlT AND DisCUSSION}

Asante's algorithm had provided some result regarding the analysis of time of death. It takes ambient temperature, weight of the body, rectal temperature and initial temperature into consideration in estimating the time of death. From the analysis, it was observed that the shorter the time of death, the more accurate the estimate the time of death (Table III).

As shown in Table III, Asante's algorithm only been tested through temperature and condition of body either naked or clothed. A new analysis from this study had been made where it had been tested with a corrective factor from Henssge nomogram. The purpose of this study is to improve Asante's algorithm by combining the algorithm with more variables from Henssge nomogram such as condition of the cloth either wet or dry, layer of cloth and condition of air or water rather than focusing only on clothed or naked body of corpse in crime cases. It will also increase the compatibility of Asante's algorithm to be used not only on land but also in water instead. Therefore, the functionality of Asante's algorithm will boost to be used in solving both land and water crime cases. A few result from Asante's algorithm with Henssge nomogram's corrective factor are shown in Table IV.

TABLE IV RESUlT FROM ASANTE'S ALGORITHM WITH HENSSGE NOMOGRAM CORRECTIVE FACTOR

\begin{tabular}{|c|c|c|c|c|c|c|c|c|c|c|c|c|}
\hline $\begin{array}{c}\text { result } \\
\text { from } \\
\text { asante"s } \\
\text { algorithm } \\
\text { with } \\
\text { henssge } \\
\text { nomogra } \\
\text { m } \\
\text { corrective } \\
\text { factorCas } \\
\text { e }\end{array}$ & $\begin{array}{c}\mathrm{Ag} \\
\mathrm{e}\end{array}$ & $\begin{array}{l}\mathrm{Se} \\
\mathbf{I}\end{array}$ & $\begin{array}{l}\text { Know } \\
\text { n the } \\
\text { time of } \\
\text { death } \\
\text { (hours } \\
\text { ) }\end{array}$ & $\begin{array}{c}\text { Rectal } \\
\text { Temperatur } \\
e \\
\left({ }^{\circ} \mathrm{C}\right)\end{array}$ & $\begin{array}{c}\text { Ambient } \\
\text { Temperatur } \\
e \\
\left({ }^{\circ} \mathrm{C}\right)\end{array}$ & $\begin{array}{c}\text { Body } \\
\text { Weigh } \\
t \\
\text { (lkg) }\end{array}$ & $\begin{array}{c}\text { Clothe } \\
\text { d ( }(+) \\
\text { Nalsed } \\
(-)\end{array}$ & $\begin{array}{l}\text { Estimat } \\
\text { e time } \\
\text { before } \\
\text { (hours) }\end{array}$ & $\begin{array}{l}\text { Layer of } \\
\text { Cloth }\end{array}$ & $\begin{array}{l}\text { Conditio } \\
\text { n of Air }\end{array}$ & $\begin{array}{c}\text { Conditio } \\
\text { n of } \\
\text { Water }\end{array}$ & 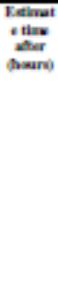 \\
\hline 1 & 51 & M & 4 & 349 & 17 & 65 & + & 3.94 & 1-2 Thin & $\begin{array}{c}\text { Moving } \\
\text { Air }\end{array}$ & $\begin{array}{c}\text { No } \\
\text { Influence }\end{array}$ & 3.80 \\
\hline 1 & 51 & M & 4 & 349 & 17 & 65 & + & 3.94 & 2-3 Thin & $\begin{array}{c}\text { Moving } \\
\text { Air }\end{array}$ & $\begin{array}{c}\text { No } \\
\text { Influence }\end{array}$ & 4.20 \\
\hline 1 & 51 & M & 4 & 34.9 & 17 & 65 & + & 3.94 & 3-4 Thin & $\begin{array}{c}\text { Moving } \\
\text { Air }\end{array}$ & $\begin{array}{c}\text { No } \\
\text { Influence }\end{array}$ & 4.32 \\
\hline 1 & 51 & M & 4 & 349 & 17 & 65 & + & 394 & 1-2 Thick & $\underset{\text { Air }}{\text { Moving }}$ & $\begin{array}{c}\text { No } \\
\text { Influence }\end{array}$ & 4.20 \\
\hline 1 & 51 & M & 4 & 34.9 & 17 & 65 & + & 3.94 & $\begin{array}{l}2 \text { or more } \\
\text { Thicker }\end{array}$ & $\begin{array}{c}\text { Moving } \\
\text { Air }\end{array}$ & $\begin{array}{c}\text { No } \\
\text { Influence }\end{array}$ & 3.51 \\
\hline 1 & 51 & M & 4 & 349 & 17 & 65 & + & 3.94 & $\begin{array}{c}\text { Thick } \\
\text { Bedsprea } \\
\text { d }\end{array}$ & $\begin{array}{c}\text { Moving } \\
\text { Air }\end{array}$ & $\begin{array}{c}\text { No } \\
\text { Influence }\end{array}$ & 4.93 \\
\hline 2 & 54 & F & 4 & 34.4 & 22 & 65 & + & 5.44 & 1-2 Thin & $\begin{array}{c}\text { Moving } \\
\text { Air }\end{array}$ & $\begin{array}{c}\text { No } \\
\text { Influence }\end{array}$ & 5.24 \\
\hline 2 & 54 & F & 4 & 34.4 & 22 & 65 & + & 5.44 & 2-3 Thin & $\begin{array}{c}\text { Moving } \\
\text { Air }\end{array}$ & $\begin{array}{c}\text { No } \\
\text { Influence }\end{array}$ & 5.81 \\
\hline 2 & 54 & F & 4 & 34.4 & 22 & 65 & + & 5.44 & 3-4 Thin & $\underset{\text { Air }}{\text { Moving }}$ & $\begin{array}{c}\text { No } \\
\text { Influence }\end{array}$ & 6.00 \\
\hline 3 & 54 & M & 4 & 35.1 & 19.3 & 78 & + & 4.29 & 1-2 Thin & $\underset{\text { Air }}{\text { Moving }}$ & $\begin{array}{c}\text { No } \\
\text { Influence }\end{array}$ & 4.12 \\
\hline 3 & 54 & M & 4 & 35.1 & 19.3 & 78 & + & 4.29 & 2-3 Thin & $\underset{\text { Air }}{\text { Moving }}$ & $\begin{array}{c}\text { No } \\
\text { Influence }\end{array}$ & 4.59 \\
\hline 3 & 54 & M & 4 & 35.1 & 19.3 & 78 & + & 4.29 & 3-4 Thin & $\underset{\text { Air }}{\text { Moving }}$ & $\begin{array}{c}\text { No } \\
\text { Influence }\end{array}$ & 4.74 \\
\hline 4 & 26 & F & 4 & 34.7 & 22.5 & 75 & - & 4.85 & Naked & $\begin{array}{l}\text { Moving/ } \\
\text { Still Air }\end{array}$ & $\begin{array}{c}\text { No } \\
\text { Influence }\end{array}$ & 4.35 \\
\hline 4 & 26 & F & 4 & 34.7 & 22.5 & 75 & - & 4.85 & Naked & $\begin{array}{c}\text { No } \\
\text { Influence }\end{array}$ & $\begin{array}{c}\text { Flowing } \\
\text { Water }\end{array}$ & 3.42 \\
\hline 4 & 26 & F & 4 & 34.7 & 22.5 & 75 & - & 4.85 & Naked & $\begin{array}{c}\text { No } \\
\text { Influence }\end{array}$ & $\begin{array}{c}\text { Still } \\
\text { Water }\end{array}$ & 3.81 \\
\hline 5 & 16 & M & 4 & 35.9 & 22.4 & 65 & - & 2.96 & Naked & $\begin{array}{l}\text { Moving/ } \\
\text { Still Air }\end{array}$ & $\begin{array}{c}\text { No } \\
\text { Influence }\end{array}$ & 2.68 \\
\hline 5 & 16 & M & 4 & 35.9 & 22.4 & 65 & - & 2.96 & Naked & $\begin{array}{c}\text { No } \\
\text { Influence }\end{array}$ & $\begin{array}{l}\text { Flowing } \\
\text { Water }\end{array}$ & 2.15 \\
\hline 5 & 16 & M & 4 & 35.9 & 22.4 & 65 & - & 2.96 & Naked & $\begin{array}{c}\text { No } \\
\text { Influence }\end{array}$ & $\begin{array}{c}\text { Still } \\
\text { Water } \\
\end{array}$ & 2.37 \\
\hline
\end{tabular}

Table III and Table IV show the different between before the corrective factor are added and after it is added are shown. The results are change due to the changes in the corrective factor variable. The result produced still reliable as the result still move around the known time of death as shown in Table IV. It producing a result which still reasonable depending on the selection of the time of death. Due to the observation, it shown that Asante's algorithm 
could be improved along with the Henssge nomogram corrective factor.

\section{CONCLUSION}

As a conclusion, many approaches of the algorithm had been used in crime investigation. This substantiation demonstrates that the algorithm can be applied or contributed in crime investigation. Table I clearly describes the significance of algorithm which had been used to solve crime cases in many related crime investigation fields. This firmly recommended algorithm relatively connected in solving crime cases such as in the criminal network field, crime data mining field, crime investigation and prevention field, forecasting for future crime in the crime data mining field and in time of death estimation field. Thus, strengthen the algorithm as a step by step process in solving a problem.

Focusing on time of death estimation, it is described as time elapse since a person died. An algorithm approach had been used to solve time of death estimation problem. The longer the post mortem interval, the time of death estimation becomes less accurate and unreliable. Algorithm approach as being recommended by Asante seems to assist in solving time of death estimation problem. However, some of the result produce from the algorithm still are unreliable and need to be improvised. [4] in their paper demonstrate the comparison of five methods used to estimate the time of death. Based on five methods which have been tested, it is found that Henssge nomogram method give the most versatile and accurate result in estimating the time of death for homicide and accidental drowning cases in crime investigation. Thus, this strengthens that Henssge nomogram method could bring great influence in time of death estimation result.

Comparing between Asante's algorithm and Henssge nomogram, these methods present a similar variable to be taken into consideration such as rectal temperature, ambient temperature, body weight and so on. Although both methods used different ways and formula in estimating the time of death, they still intend to achieve the same objective which is the time of death. Due to similarity in variables, the enhancement of Asante's algorithm with Henssge nomogram method is assured to improve the result in estimating the time of death.

Last but not least, the reference of consideration in enhancing Asante's algorithm with Henssge nomogram could provide a better result in estimating the time of death coincide with its intention in making the result become more accurate and reliable. It will provide the algorithm to be in a right track, improve its performance, became more reliable and worthy.

\section{ACKNOWLEDGMENT}

The authors would like to thank for continuous supports given by Datuk Jamshah Mustapa, Chief Officer of Criminal Investigation Department Terengganu, Royal Police Malaysia (RPM). This work was supported by grant from Fundamental Research Grant Scheme (FRGS), Ministry of Higher Education (MOHE) with vot number 59289.

\section{REFERENCES}

[1] A. Ugbe, R. O. Arop, and G. I. Akper, Basic Elements of Criminal Investigation, 2013

[2] M. B. C. Abdullah, N. M. Noor, and Z. A. Bakar, "The incorporation of algorithm with Newton law of cooling as a methodology to estimate the time of death of corpse or cadaver," in Proc. International Conference on Artificial Intelligence and Computer Science, 2014.

[3] H. J. Byrd and L. James, Forensic Entomology: The Utility of Arthropods in Legal Investigations, CRC Press, 2012.

[4] P. J. Karhunen, O. Winberg, and M. Tuominen, "Time of death of victims found in cold water environment," Forensic Science International, 2007.

[5] J. J. Xu and H. Chen, "Fighting organized crimes: using shortest-path algorithms to identify associations in criminal networks," Department of Management Information Systems, University of Arizona, 2003.

[6] H. Chen, W. Chung, Y. Qin, M. Chau, J. J. Xu, G. Wang, H. Atabakhsh, "Crime data mining: An overview and case studies," Artificial Intelligence Lab, Department of Management Information Systems, University of Arizona, 2003.

[7] J. Keppens, Q. Shen, and M. Lee, "Compositional bayesian modelling and its application to decision support in crime investigation," Department of Computer Science, University of Wales, Aberystwyth, UK, 2005.

[8] S.-T .Li, S.-C. Kuo, and F.-C. Tsai, "An intelligent decision-support model using FSOM and rule extraction for crime prevention," Expert Systems with Applications, 2010.

[9] A. Malathi and S. S. Baboo, "An enhanced algorithm to predict a future crime using data mining," International Journal of Computer Applications, 2011.

[10] S. Asante, "Application of newton's law of cooling case study: Estimation of time of death in murder," Kwame Nkrumah University of Science and Technology, 2013.

[11] V. J. DiMaio and D. DiMaio, Forensic Pathology Second Edition, United States of America: CRC Press LLC, 2011.

[12] C. Henßge and B. Madea, "Estimation of the time since death in the early post-mortem period," Forensic Science International, pp. 167175,2004

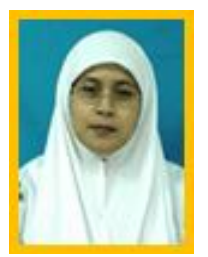

Noor Maizura Mohamad Noor is currently a deputy dean of academic and students. Previously she was a deputy director of Quality Centre and Academic Development (PKPA) Universiti Malaysia Terengganu (UMT). She received her $\mathrm{PhD}$ degree from The Manchester University, UK in 2005. Her recent research work focuses on improving organizational decision making practices through the use of technologies. This includes research interests in the design, development and evaluation of decision support systems for analyzing and improving decision processes. Her research interests also focus on the areas of computer science, intelligent decision support system, clinical decision support system, and information system. She is an editor of books, conferences proceedings and also a reviewer and editorial board of International Journals. Her contribution to scientific computing has been recognized by receiving several awards including the Best Scientist Award (2009), Product and Research Innovation Award for International and National Level (2008 and 2009) of UMT. She is a member of ACM and IACSIT.

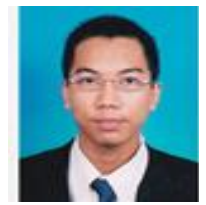

Muhammad Bin Che Abdullah is currently a master degree student in Computer Science Department, University Malaysia Terengganu. He received degree in computer science major in software engineering from University Malaysia Terengganu in 2012. His research interest is in network application and decision support system.

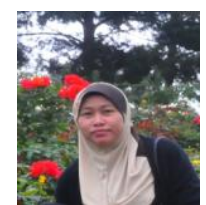

Zuriana Abu Bakar is currently lecturer in Computer Science Department, University Malaysia Terengganu. She received her PhD from Queensland University. Her area of expertise is in human computer interaction and her research interest is in interaction design, affective computing and forensic computing. 